\title{
13. Enhancing social partners' capacity and social dialogue in the new world of work: The case of Spain
}

\section{Oscar Molina}

\section{INTRODUCTION}

Since the transition to democracy, social dialogue in Spain has played a key role in coordinating collective bargaining, regulating the labour market and governing socio-economic policy-making. It has become a defining trait of the industrial relations system and a central element of the governance of the socio-economic model. Its importance and intensity has evolved in accordance with the economic and political context, however.

During the financial and sovereign debt crises, tripartite social dialogue was temporarily abandoned in the context of the implementation of austerity policies. The sovereign debt crisis not only led to the implementation of far-reaching fiscal austerity packages in the peripheral countries of the Eurozone, but it also triggered significant reforms of labour market institutions, industrial relations and welfare states. The political and economic context in which crisis-induced austerity reforms occurred was certainly propitious to the abandonment of tripartite concertation and social dialogue (Molina and Miguélez 2013; Pedersini and Regini 2013; Guardiancich and Molina 2017). The explicit or implicit external imposition of these reforms on governments under strong pressure to comply with fiscal stability led, in many cases, to unilateral reforms.

The abandonment of tripartite social dialogue and the adoption of a unilateral approach to policy-making in areas such as labour market regulation, industrial relations and the welfare state is not novel, however. The ups and down of tripartite social dialogue are related to three main characteristics of industrial relations in Spain. First, its weak and late institutionalization, since policy concertation has developed outside institutional mechanisms such as the tripartite Economic and Social Council. Second, it has mainly dealt with issues with a strong distributional character, while having a limited impact on general economic policy-making, except during the early 1980s. Finally, and as a consequence of the above, its discontinuance depended on the economic cycle and the colour of the governing party (Espina 1999). These three interlinked features have been exacerbated as a consequence of the recent economic crisis and help to explain the collapse experienced by tripartite concertation and the weakness of social dialogue during this period.

However, the crisis added new tensions and obstacles to the development of social dialogue. First, the tightening of fiscal rules and the macroeconomic surveillance mechanisms severely limited governments' room to manoeuvre and possibilities for 
engaging in political exchange with the social partners, even in a post-crisis recovery scenario. Second, the democratic and institutional crisis that has also affected the social partners has further reduced governments' incentives to involve them in policy-making (Culpepper and Regan 2014).

\subsection{Late Revitalization of Social Dialogue in the Post-crisis Period}

In the post-crisis period there has been a belated and only timid recovery of tripartite social dialogue. Industrial relations developments in the period 2014-19 were characterized by institutional stability, after the convulsions experienced in the previous period of the crisis. The social partners have tried to find a new equilibrium and rebuild consensus after the many reforms that have taken place since 2010, culminating with the 2012 unilateral reform that introduced far-reaching changes in the labour market and collective bargaining institutions. More specifically, trade unions have tried to halt the trend towards decentralization of collective bargaining and to neutralize the negative effects of the reform of automatic extension of collective agreements.

After its abandonment in 2011, social dialogue struggled to revitalize in the 2014-19 period. Despite the economic and labour market recovery, tripartite social dialogue has remained weak and limited in scope (Molina and Miguelez 2017). A long-term process, consisting of narrowing the issues negotiated in tripartite social dialogue, has also contributed to detaching social dialogue from economic policy-making. In this vein, the European Semester and the negotiation and implementation of National Reform Programmes can be considered missed opportunities for strengthening tripartite social dialogue. The 2012 reform remains a major source of disagreement among social partners, with the trade unions pushing to remove it before any dialogue on reforming the labour market and industrial relations takes place. Finally, political instability since 2015 has also had a negative impact on the revitalization of social dialogue that has only gained momentum since 2018. Since 2015 there have been four general elections as a consequence of the fragmentation of the political party landscape and the difficulties experienced in forging a majority in Parliament. Moreover, in June 2018 the right-wing government headed by Mariano Rajoy lost a no-confidence vote and the socialist Pedro Sánchez became the new prime minister. However, the new socialist government is also facing significant problems putting together a stable majority and, since then, two general elections have taken place.

Notwithstanding these problems, social dialogue has delivered some outcomes over this period. Social dialogue gained momentum in 2018 after several years of recovery following the period of unilateral policy-making during the crisis and austerity policies. In early June 2018, the Parliament appointed the Socialist Party's Pedro Sánchez as the new prime minister after winning a no-confidence vote. In the following ten days, the new head of the executive had two tripartite meetings with trade unions and employer organizations in order to open a new social dialogue cycle and start negotiations on several issues, including a 'Plan for decent work'. With these meetings, the new government transmitted to the social partners its strong commitment to social dialogue and willingness to give it further momentum, after the modest revitalization experienced since 2015 .

These agreements have helped to recover workers' employment and social rights lost or eroded during the crisis. These included agreements for public sector employees, a 
bipartite peak agreement in 2018, the fight against youth unemployment and precariousness. Particularly important is the role played by social dialogue between unions and employers and their efforts to restore the autonomy lost by unilateral government regulation of collective bargaining during the crisis. Both trade unions and employers have an interest in maintaining their institutional position in the industrial relations system and collective bargaining, and as a consequence have developed autonomous mechanisms to enhance its coordination and governability.

In this chapter we explore the role of social dialogue in addressing some of the most important challenges facing industrial relations institutions and actors in Spain, and how to enhance social partners' capacity to face them through social dialogue. Section 2 provides an overview of the main features of industrial relations in Spain, together with the main challenges identified by the social partners. Section 3 contains an analysis of: first, the challenges in relation to representativeness, the decline in membership and the mechanisms for addressing them; second, the role of the state in industrial relations; and, finally, the impact of the digital economy, with a particular focus on the platform economy.

\section{MAIN CHALLENGES FACING INDUSTRIAL RELATIONS IN SPAIN}

Industrial relations in Spain exhibit three distinctive features compared with other European Union (EU) countries. The first is a fragmented and weak trade union movement from an associational point of view. The second feature is the pervasive role of the state in regulating industrial relations and collective bargaining (Molina 2014). The final feature is a collective bargaining system with high coverage levels owing to the automatic extension of agreements and the predominance of sectoral negotiations.

The trade union movement that emerged during the transition to democracy in Spain is an attenuated duopoly of two large national confederations (Unión General de Trabajadores, UGT, and Comisiones Obreras, CCOO), together with a number of small professional and/or regional confederations. The CCOO was close to the Communist Party (Partido Comunista de España, PCE) in the transition to democracy, while the UGT maintained close links with the Partido Socialista Obrero Español (PSOE). The two confederations account for 70 per cent of elected representatives in works councils and define themselves as class-based trade unions, covering all sectors of the economy.

The crisis has aggravated some of the structural weaknesses of trade unions, while posing new challenges for them (Barranco and Molina 2014). In this vein, some authors have noted that trade unions have lost both the power and the social legitimacy to force governments to involve them in the policy-making process (Culpepper and Regan 2014). This is explained not only by their declining membership, but also by the identification of trade unions as part of the political system, and hence the causes of the economic crisis not as part of the solution to it. These two faces of the crisis have put trade unions in a different scenario compared with previous crisis episodes as their monopoly in channelling social discontent has been contested. New social movements and other civil society actors have played a more prominent role in gathering and organizing anti-austerity movements (della Porta 2015). In doing so, they have relied upon mass protests and 
demonstrations from which trade unions have often been excluded, played a marginal role or have themselves been the target of protests as part of the political status quo. Increasing membership and regaining social legitimacy currently constitute significant challenges for trade unions, and they are trying to develop strategies to recruit members and gain representativeness (see section 3 in this chapter).

The state's role is also a distinctive feature of the Spanish industrial relations system (Molina 2014). The consolidation of democratic institutions and the opening up of spaces for autonomous self-regulation and interaction among the social partners have characterized industrial relations developments since the early 1980s. However, this process has been characterized by a comparatively higher degree of state intervention in order to overcome some of the coordination problems among social partners that appeared in the early years of the return to democracy. This is a differentiating trait of the Mediterranean or mixed variety of capitalism (Amable 2003; Molina and Rhodes 2007). In return for cooperation in the early stages, the state has often provided the social partners, and especially the trade unions, with institutional compensation, including their participation in public policy-making, extension mechanisms for collective bargaining, and so on. Owing to this, the social partners have achieved institutional and political power that far exceeds their real influence in terms of membership or company-level representation. Moreover, a production structure that makes it difficult for the unions to reach many workplaces has hindered the development of a strong bargaining coordination capacity. Laws extending collective agreements have accordingly played a key role in governing industrial relations. We can therefore expect the state to face greater incentives to adopt a unilateral approach to policy-making in Spain, particularly in the context of economic crises. Even though the social partners feel they enjoy considerable autonomy in relation to collective bargaining, they nonetheless agree on the need to consolidate and enhance this autonomy, as explained in section 4.

In relation to collective bargaining, Spain is characterized by a multi-level bargaining structure, with a historically weak articulation between levels (Martin Artiles and Alos Moner 2003). In the early years after the transition to democracy, collective bargaining occurred at several levels, with negotiations at territorial (provincial) sectoral level being the most significant in relation to workers covered. However, negotiations took place in several bodies, and the issues were often renegotiated at lower levels, leading to cascading negotiations. The hierarchy principle in the Labour Code (Estatuto de los Trabajadores) made it very difficult for company-level agreements to dilute the conditions negotiated at a higher level. Peak agreements in the early 1980s contributed to maintain a formally high level of centralization, but after its abandonment after the mid-1980s, a process of gradual decentralization has occurred owing to the lack of a coherent articulation between bargaining levels. The limited presence of unions at enterprise level hindered the efficacy of collective negotiations at higher levels as they could only occasionally reach workers in small and medium-sized establishments. As a consequence, collective bargaining was very sensitive to changes in actors' strategies, preferences and power, which undermined its stability and became a permanent source of conflict, as shown by the comparatively high conflict rates.

Peak cross-sectoral agreements since the mid-1990s have helped to govern and coordinate collective bargaining in Spain and to maintain a formally high level of centralization. 
Despite this, a process of decentralization has been in place since the early 1990s, as a consequence of changes in collective bargaining regulations. The trend towards collective bargaining decentralization has accelerated in the context of the crisis and has adopted a clear bottom-up, disorganized character. This has eroded the regulatory capacity of sectoral agreements. We may expect this to reduce the incentives for governments to engage in tripartite concertation with the social partners owing to of their lower capacity to steer industrial relations developments.

\subsection{Strengths, Weaknesses, Challenges Ahead and the Role of Social Dialogue}

The main strengths of the industrial relations system in Spain are its institutionalization, on the one hand, and the strong consensus among the most representative social partners around its key features, on the other. The second aspect is well reflected in the peak bipartite cross-sectoral agreements on employment and collective bargaining (see section 4 in this chapter). These are signed every two years and provide general guidelines and orientation for collective bargaining. The strong institutionalization of the industrial relations system can be observed at all levels and dimensions, and consists in intensive legal regulation, from the rules for representativeness of social partners, to the erga omnes extension of collective bargaining, trade union workplace elections or the articulation between levels in the collective bargaining structure. Together, these characteristics explain the resilience and stability of the industrial relations system in Spain.

There are, however, some developments that pose important challenges for the future of the system. Four are particularly important for Spain, according to those interviewed. The first is the role of the state in industrial relations and the autonomy of the social partners, an aspect that is a current matter of concern for trade unions and employer organizations. Even though, since the transition to democracy, the state has intervened unilaterally, particularly during periods of economic crisis, this trend seems to have become stronger since the Great Recession. Even in a context of economic recovery and with a left-wing government since June 2018 that emphasized its commitment to social dialogue, the social partners have expressed their discomfort with some decisions, including the unilateral increase in the minimum wage, the unilateral approval of a law for registering working time or their limited involvement in the most recent phase of the European Semester process. The social partners consider that governments of different colours have often intervened in policy issues that should be dealt through tripartite social dialogue. To an extent, these developments show the fragility of collective selfregulation in countries with statist traditions under the external pressures of economic adjustment. The state still plays the role of coordinator and regulator of last resort, as has become evident in the recent economic crisis and its aftermath.

A second challenge for the industrial relations system is the low levels of union membership, particularly among younger groups, and the trend towards fragmentation in the trade union landscape (Alós et al. 2015). Low levels of union membership and the decline in citizens' trust in trade unions can also be considered a weakness, and challenge the capacity of trade unions. Even though low membership levels have been a historical feature of trade unions in Spain, the decline in trust experienced since the Great Recession constitutes another cause for concern for them, as it might make it even more difficult to recruit new members, while eroding its legitimacy. The trade unions consider 
that there is a strong cyclical pattern in this indicator and it is already recovering from the low levels reached in the worst years of the Great Recession, but it confirms the need to make greater efforts at reaching new groups of workers. Moreover, there has been growth in recent years in occupational, regional and yellow trade unions (a trade union which is dominated or influenced by the company/employer). Even though this could be interpreted as a sign of the vitality of the trade union movement, it will nonetheless pose an important challenge to the future governance of the system. For instance, it could lead to an increase in conflict levels, or to growing difficulties in implementing collective agreements.

A third risk facing industrial relations in Spain is the trend towards disorganized decentralization and the enhanced power of the employers that was inherited from reforms implemented during the Great Recession. The objective of these reforms was to enhance employers' capacity to adjust collective agreements or simply to opt out of them, thereby pushing labour relations closer to the market (Rodríguez et al. 2016). This may also further erode the social partners' capacity to govern industrial relations in the future, in the context of the digital transformation and the growth of the number and types of outsourcing practices.

The final challenge is the impact of the digital economy on industrial relations and collective bargaining. Even though the digital economy is a multi-dimensional concept, the discussion here focuses on two aspects that are currently on the agenda of the social partners and/or government: first, the use of digital mechanisms for monitoring and surveillance at the workplace; and second, the extension of platforms and platform work and the challenges associated with it.

\section{REPRESENTATIVENESS, MEMBERSHIP AND SOCIAL PARTNER LEGITIMACY}

Representativeness and membership are linked to the input legitimacy of social dialogue. The higher the representativeness and affiliation to the social partners, the stronger and perhaps more effective social dialogue will be. Also, the legitimacy of the social partners depends on their capacity to deliver to their members. Thus a key element of enhancing their capacity is to enlarge the membership base and strengthen their representativeness.

As regards Spain, representativeness and membership are not directly related. There are clear rules defining representativeness that are independent of affiliation. The social partners agree in their support for these rules and coincide in identifying some beneficial outcomes, including a higher degree of governability of industrial relations and lower levels of industrial conflict. On the union side, increasing membership levels remains a top priority, even though representativeness rules are not based on membership. However, the unions admit that the institutional context and the characteristics of the labour market make it very difficult to attract new members. The unions are paying growing attention to attracting young workers and this is partly why they are also focusing on occupations or activities with a predominantly young workforce. This applies, for instance, to the platform economy. 


\subsection{Workplace-level Employee Representation Structures and Trade Union Elections in Spain: Election-based Representativeness}

One of the defining traits of the Spanish industrial relations system is the way in which representativeness is defined. Contrary to other EU industrial relations systems, representativeness is based on work council election results (number of delegates elected), not union membership. The most representative trade unions at company, regional or sectoral level will participate in the negotiation of collective agreements. Also, the automatic erga omnes extension of collective agreements is a key element in explaining the relatively low trade union density in Spain (around 15-20 per cent of the workforce), as it endows the most representative trade unions and employer organizations with the capacity to negotiate agreements on behalf of all workers in the sector or company in which the agreement is negotiated, but reduces the incentives for workers to join trade unions.

The specific socio-political and institutional context during the early years of the transition determined the most important power resources of trade unions in Spain. As noted by Jordana (1996) the rapid increase in trade union membership and workers' mobilization in the early months of the transition was rapidly brought under control by the two largest union confederations, the CCOO and the UGT. In exchange for their role in channelling workers' discontent through negotiation and institutional participation, they were granted a strong institutional role and detailed legal regulation of collective bargaining. By contrast, on other traditionally important power resource indicators, the position of Spanish trade unions is weakening. This includes associational power resources, owing to the low membership levels, and organizational power, as a consequence of the increasing difficulty of mobilizing their members and getting them to play an active role. By contrast, they have a relatively strong mobilization capacity that far exceeds their organizational and associational power. Another key power resource of trade unions in Spain, the structure, is also under stress owing to the downsizing of the public sector, as well as the increase in temporary employment.

Through the concept of 'most representative organizations', employers' organizations and trade unions are entitled to conclude multi-employer collective agreements, to have institutional representation (that is, to be a part of tripartite bodies, to be consulted by the government and to conclude social pacts) and to take part in extrajudicial forums of labour conflict resolution. Moreover, meeting the criterion of legal representativeness is the basis for gaining access to public funds.

The main bodies for workplace representation in the private sector are personnel delegates and works councils. In the public sector, workplace-level representation is achieved through the Juntas de Personal. Staff delegates are responsible for representing workers in those establishments and workplaces with between 11 and 49 employees. There may also be a personnel delegate in companies with between six and ten employees, if a majority of the employees agree. In companies with up to 30 employees there may be one personnel delegate, and three in companies with between 31 and 49 employees.

\subsection{Are Representativeness Rules Contested?}

The interviews revealed a general consensus on the existing representativeness rules in Spain. The most representative trade unions and employer organizations consider that 
these rules have allowed a high level of governability of employment relations, while reducing conflict levels. However, some trade unions and economic/political actors think these rules could be revised or improved.

On the one hand, smaller trade union confederations and other professional trade unions criticize the representativeness criterion as it constitutes an obstacle to trade union involvement, but also to the growth of smaller organizations. For this reason, a few years ago some smaller confederations filed a complaint that these rules go against freedom of association. The Constitutional Court established in several rulings that the representativeness rules in Spain do not violate the right to freedom of association since the advantages conferred by this condition constitute a positive that favours and enhances trade union action, but does not deprive the remaining unions of any essential instrument for fulfilling their objectives. Similarly, the constitutional principle of equality is not affected as the differences between the unions are established on an objective basis, election results, which counts as the best defence of the interests of the workers.

According to the interviewees from the most representative trade unions in Spain (the CCOO and the UGT), although the representativeness criteria could be improved, the criterion based on works council elections is more inclusive and guarantees that trade unions can reach a vast majority of workers, in contrast to a membership-based criterion. This is particularly so in an economy characterized by a fragmented and atomized production structure, with a predominance of small and micro companies.

Figures 13.1 and 13.2 show the distribution and evolution of works council election results. Even though the CCOO and the UGT maintain a dominant position in works council elections at state level (Figure 13.1), this position has weakened in recent years (Figure 13.2). According to the most representative trade unions at national level, a number of factors account for the decline in the percentage of delegates elected in works council elections:

1. The closure of establishments/companies during the Great Recession, which has most affected companies in which where the two largest trade unions had a stronger presence (including manufacturing).

2. Employers' development of strategies to weaken and interfere with class-based trade unions. These include supporting the creation of alternative, yellow trade unions.

\subsection{Trade Union Membership: Trends and Composition}

Most studies categorize Spain as a country that historically has had relatively low union membership (Beneyto et al. 2016; Rigby 2016; Jódar et al. 2018). The evolution of membership levels in Spain has not followed the same downward pattern as in other EU countries. Since the 1980s there has been sustained growth in the number of affiliates, although at a slower rate than the growth of the active population. Union membership reached a peak in 2010 and then declined until 2016, when it started to increase again. The manufacturing sector has been a traditional trade union stronghold, and has a higher density of membership than in other sectors. However, with the decline in the gross domestic (GDP) share of manufacturing, together with growing outsourcing, the service sector and, in particular, public services currently concentrate a significant share of trade union members in Spain. 

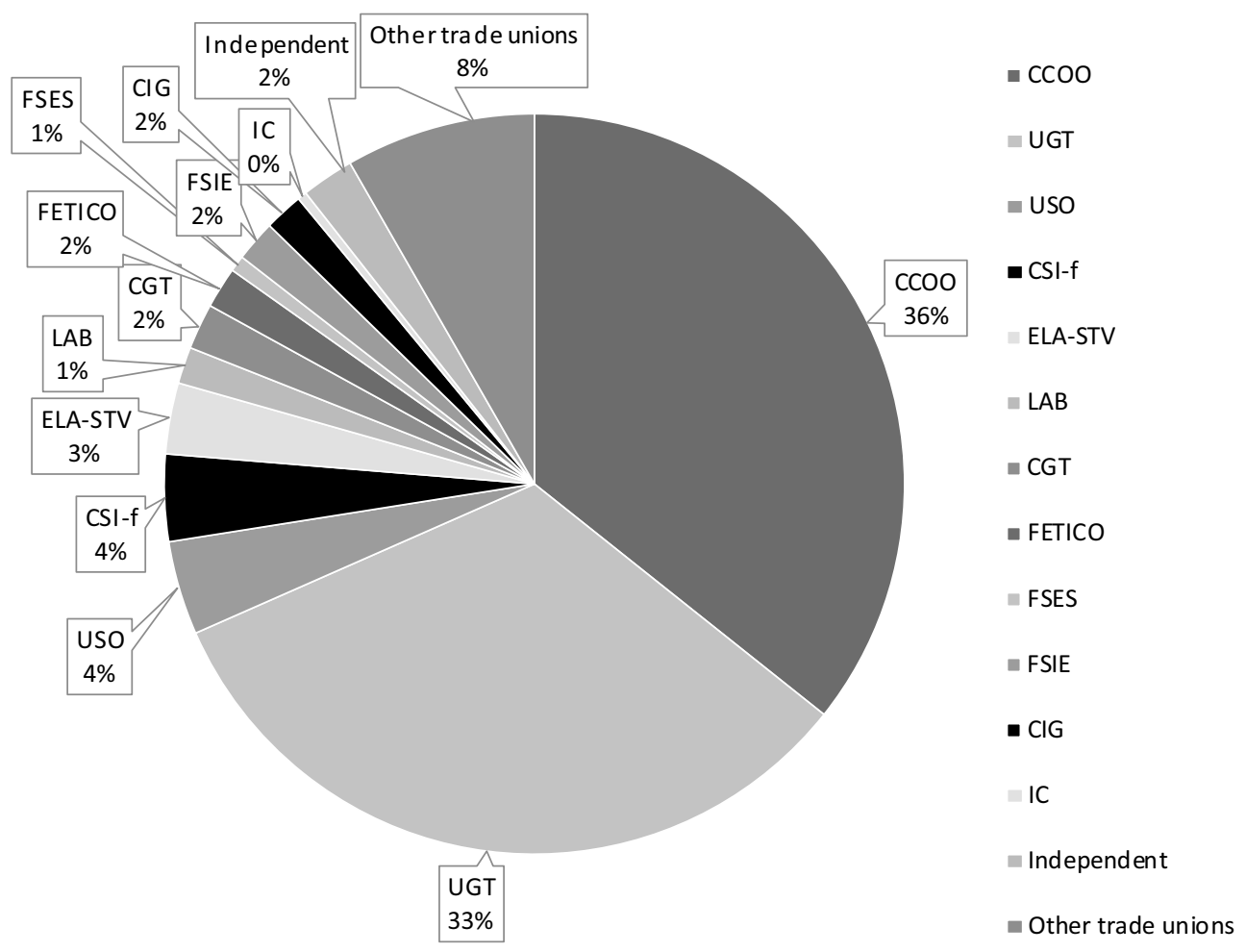

Figure 13.1 Distribution of delegates elected, 2015-19 (percentage)

The low trade union membership levels are a combination of several factors:

1. Institutional - automatic extension of collective agreements and the use of electoral criteria to determine trade union representativeness.

2. Organizational - complex multi-level organizations with regional and sectoral federations, but with a moderate level of centralization, making it difficult to develop effective organizing strategies (see Martínez Lucio 2003).

3. Structural - a production system in which small and very small companies predominate, and there is a strong seasonal component in important sectors, as well as a large share of workers in non-standard forms of employment.

4. Social/cultural - historically low levels of civic engagement in Spain.

Köhler and Calleja (2011) highlight two characteristics in the evolution of trade union membership figures in the pre-crisis period. First, Spain is one of the few EU countries where membership in absolute numbers increased. However, as this period also witnessed strong employment creation, union density remained stable. Secondly, the composition of trade union membership in Spain changed in the growth period preceding the economic crisis, but very slowly. This means that the traditional under-representation of some groups, such as women, foreign workers or young people, remains a trait of trade 


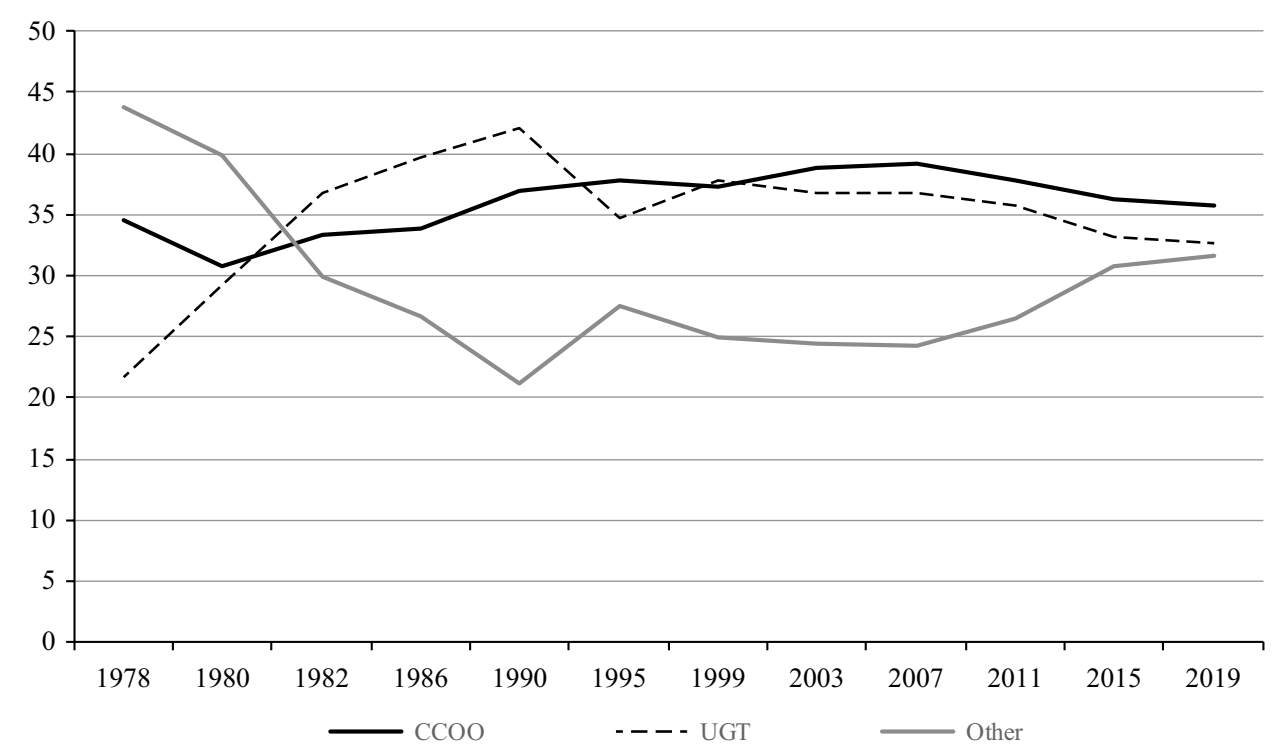

Figure 13.2 Evolution of shares of delegates elected, 1978-2019

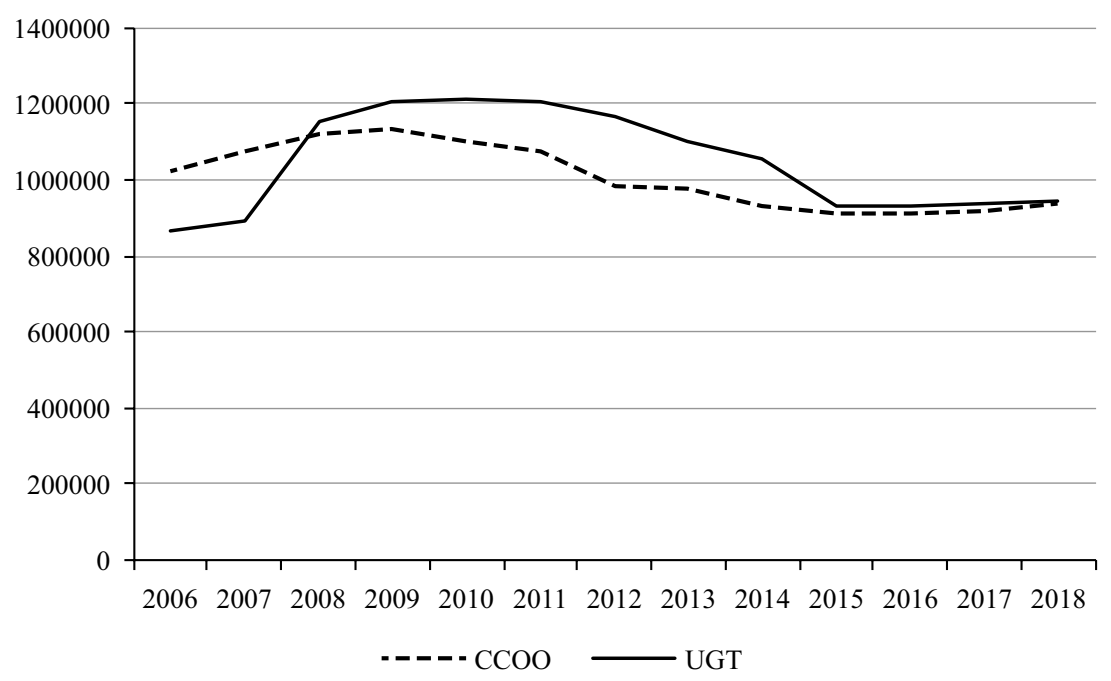

Figure 13.3 Trade union membership levels in Spain, 2006-18

unions in Spain. The increase in membership registered in the pre-crisis period, together with the maintenance of a strong role in collective bargaining and the political sphere, has hindered the process of organizational renewal within the unions that many authors consider key to increasing membership (Behrens et al. 2004).

When studying the composition of union members in Spain, the first problem is the lack of available union data. There is no publicly accessible registry and/or database providing 
data on official membership levels, and when publicly available, the data provided are not disaggregated by age, sex and so on. That means that union membership and density data are self-reported by trade unions, difficult to access and hardly comparable. Overall, this poses significant difficulties for the study of trade union membership in Spain.

The only survey-based data available for studying the level and composition of union membership in Spain was the Encuesta de Calidad y Vida en el Trabajo (ECVT; Quality of Life at Work Survey), which was discontinued in 2010. We can summarize the characteristics of trade unionism in Spain based on the final round of the survey:

- Low to moderate membership rate (21 per cent of employees).

- High collective bargaining coverage rate (between 80 and 90 per cent).

- The majority of members have an open-ended contract (87.3 per cent).

- Higher membership in large companies (32 per cent affiliation rate in companies with more than 250 workers, but a mere 7 per cent affiliation in those with fewer than ten workers).

- Higher membership in the public sector (one in three public sector workers are affiliated, while in the private sector, only one in six employees was a trade union member in 2010); within the private sector, there is greater union density in industry than in services.

- The older and more experienced the worker, the greater likelihood of union membership (one-third of those over 50 are members, but only 15 per cent of those under 30 are). The mean age difference between members (44 years) and nonmembers (40 years) is gradually increasing and it seems that a decreasing number of young people are joining trade unions.

- Higher membership among men than among women (23.2 per cent of men and 18.2 per cent of women). The differences in gender affiliation have been significantly reduced in recent years, with an increase in members in the service sector.

- A similar level of education between non-members and non-members.

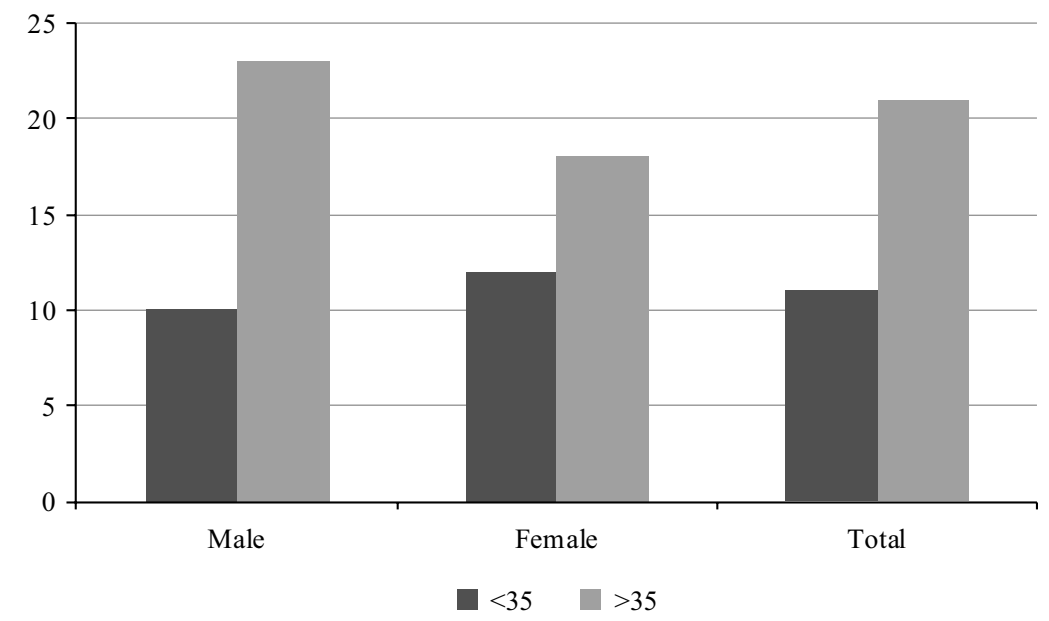

Figure 13.4 Trade union density in Spain by age group and sex, 2010 
According to this survey, the trade union density of those aged below 35 years of age is half that of those above 35 years old. The difference is lower for women than men. When we look into the differences by type of contract we find how being in a temporary contract constitutes an important factor for non-affiliation to a trade union. In both age groups, the affiliation is lower for workers with a temporary contract, but significantly lower as regards younger workers (Figure 13.5). This means that temporary workers have fewer incentives to become a union member, and the temporary-contract effect outweighs the age effect.

A static analysis of membership figures needs to be complemented with a more dynamic approach based on flows in and out of trade unions. This is particularly important for the unions as they aim to renew their membership basis by increasing the inflow of young people to make up for the outflow of older workers. Moreover, membership turnover in Spain is very high. Vidal et al. (2014) presented short-lived union membership, using the case of the CCOO. According to this analysis, more than 10 per cent of new members left the union after only 12 months, suggesting that there is a high turnover among recent joiners, probably owing to a change in job situation or after using union services (Jódar et al. 2011). In this vein, an instrumentalist approach towards trade unions explains the high quit levels, especially among young workers. Moreover, there is an obvious difference in the levels and speed of leaving among the youngest age group, evidently the most vulnerable, and other age groups: 20 per cent of the youngest age group left the union before the second year of membership. This highlights the need to pay more attention to retention of existing members, not just to attracting new members, which has been the main concern of trade unions thus far.

Retaining young temporary workers is very difficult. The problem is that the time lapse between labour market entry and a young person's first stable, open-ended contract is becoming longer. Moreover, this period is characterized by frequent unemployment spells and changes in contractual position, sector, company, and so on. This implies that the young person will spend a long period without having any contact with

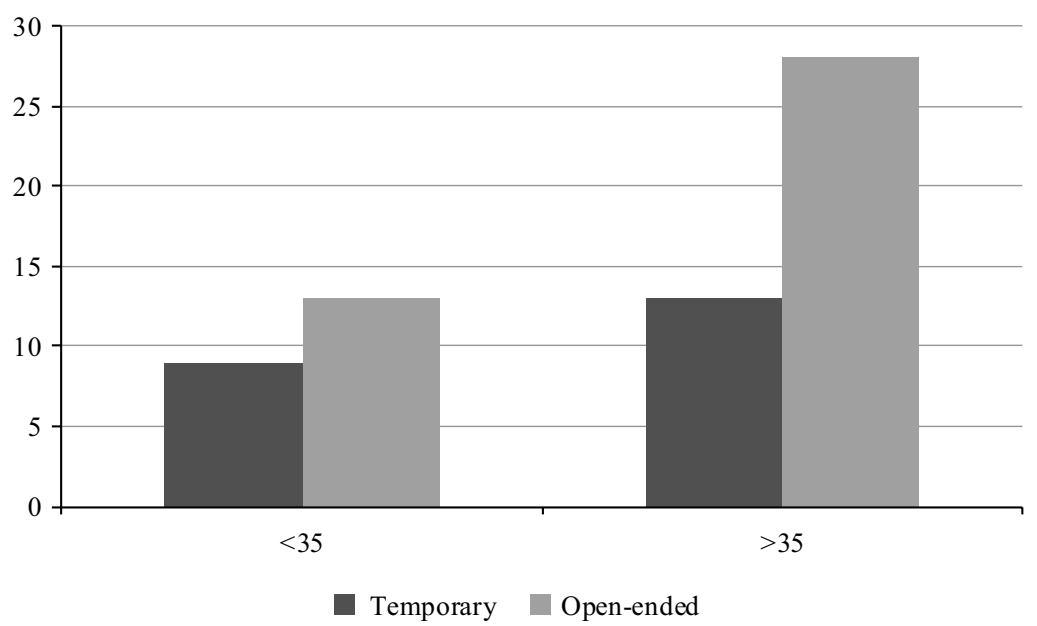

Figure 13.5 Trade union density in Spain by age group and type of contract, 2010 
trade unions, hence decreasing their probability of joining in the future, as used to be the case. According to the trade unionists interviewed, this is the real problem in relation to the membership of young people, not that young people have unstable membership careers. Longer stabilization trajectories mean less contact with trade unions, hence making it less likely that they will become members even if they do get an open-ended contract.

\subsection{Strategies for Attracting New Members and Tackling Membership Decline}

In the interviews with the two largest trade union confederations, different approaches to curbing membership decline were discussed. However, they agreed on three general considerations. First, the institutional context in Spain (and more specifically, the automatic extension of collective agreements) is a significant obstacle to increasing membership levels. Second, changes in the labour market and the organization of work pose additional difficulties to recruiting new members. Finally, there is no magic recipe or single best strategy, but they agree on combining elements from different approaches.

\section{In the workplace; beyond the workplace}

Both trade unions agreed on the importance of extending trade union organization and representation strategies to attract new members beyond the workplace. The changes in the ways companies organize their activities, including the fragmentation of production units through outsourcing, makes a narrow focus on workplace representation insufficient. It is therefore necessary to move beyond the workplace, paying particular attention to the local level to reach, organize and represent workers. Thus, for platform workers, and more specifically, riders, local forms of organization are the only mechanism for reaching these workers owing to the absence of a physical workplace. This poses a challenge as trade union organizations and structures are tailored to a different, Fordist, institutional and socio-economic setting, and are difficult to change. That is, local-level representation and organization need to strengthen this level within the trade union structure, something that is already ongoing, according to the unions, but that is difficult in a context of limited resources.

Even though there are strong incentives for trade unions to move beyond the workplace, in relation to both their representation structures and agenda, they also acknowledge that, currently, the best way to attract new members is to have strong workplace representation structures (staff delegates or works councils). These representation structures are, for many workers, the best and most effective way to get in touch with the union.

Related to this point, the organizing strategy has often been presented as an effective method for expanding membership and extending organization and coverage in sectors traditionally unlikely to unionize. Organizing is a concept of union recruitment and mobilization first developed by US service unions and is based on the organization of solidarity in a given territory and group, for example, the cleaning workers in a neighbourhood or the security workers of a port area or an industrial district. Through services and campaigns in this area, the unions plan to reach these dispersed and fragmented groups with precarious jobs and organize them as a grassroots community with a capacity for self-organization. It has reaped some success in Anglo-Saxon countries 
in which neoliberal deregulation policies have been imposed, weakening union power (Vandaele and Leschke 2010).

There is an abundant literature on this union strategy in other countries, but very few experiences in Spain, where the strong institutionalization of trade unions and collective bargaining, together with representativeness rules, constitute a significant obstacle to developing such strategies.

\section{Endorse a broader agenda}

Shifting trade union action beyond the company necessarily leads to the adoption of community issues not necessarily linked to workers' representation activities or working conditions at company level. This means that the scope of trade union action should not be limited to workplace issues, but encompass community-related aspects, in line with the logic underlying social movement unionism (Turner and Hurd 2001; Köhler and Calleja 2015). Moreover, trade unions are well aware of the importance of including other issues or demands in their agenda as socio-political actors, including climate change, feminism, depopulation of rural areas and demographic change. According to trade unions, during the crisis but also the post-crisis period, trade unions have reinforced this dimension and accordingly have become very active in supporting the $8 \mathrm{M}$ feminist strikes and the whole feminist movement. They have also made stronger efforts to include environmental sustainability issues in their policy-making, including collective bargaining.

\section{'Make the union useful' as general recruitment strategy}

Spain's low union membership is the result of a number of factors. Some are common to other EU countries and help to explain the long-term decline in union membership in all of them (Vandaele 2019): the growth of the services economy, changes in the labour market and the extension of non-standard and precarious employment, the extension of new business models, and so on.

However, the low membership levels specific to Spanish trade unions are explained mainly by institutional factors and, as noted earlier, two are particularly important. First, automatic erga omnes extension in collective bargaining whereby both unionized and non-unionized workers are covered by collective agreements. Second, the Spanish model of union representativeness based on works council elections. Under this system, the institutional presence of trade unions is to a large extent based on electoral criteria, in the specific electoral unit and in all sectoral and territorial dimensions.

These characteristics of the Spanish industrial relations system have important consequences for union membership. The main and most significant is the disincentive to join unions, as the automatic extension of collective agreements means that they apply to all workers, regardless of affiliation, and not just to the signatory party. However, the system also introduces stronger incentives for trade unions to act as electoral machines that capture votes, rather than affiliates, since union (institutional) power is obtained mainly through the computation of elected workplace representatives. As a consequence of this, we observe that the low union membership in Spain exhibits a pro-cyclical pattern. For instance, during the Great Recession, trade unions lost approximately 500000 members, in a context of high unemployment, deteriorating working conditions and an increasingly negative social perception of trade union organizations (see Figure 13.3). Moreover, the workplace representation system entails only a modest direct role for 
union delegates at workplace level, owing to the predominance of works councils and the low levels of affiliation.

Since an important trade union power resource in Spain is institutional and not associational (Rigby 2016; Calavia and Rigby 2019), few innovative strategies are devoted to attracting new members, stabilizing their affiliation and tackling membership decline. More specifically, as the institutional setting hinders trade union affiliation by limiting incentives for members, campaigns have focused on stressing the role played by unions as the main instrument for workers' representation, a mechanism for protecting labour rights and fighting against precariousness.

As union officials recognize, these initiatives are aimed not only at increasing membership, while aware that the institutional obstacles are huge, but also at enhancing the unions' representative role (that is, improving their results in workplace elections), which is considered key in their role as socio-economic and political actors.

For this reason, the strategies for attracting new members tend to emphasize general aspects of unions' roles in society, such as how useful trade unions can be for workers. That is, owing to the lack of strong selection incentives, affiliation is considered to be largely dependent on the perception of the trade union as the most effective actor for representing and defending workers' interests. This is why the most representative trade union confederations in Spain are so keen on strengthening their institutional and representation capacities (Vidal et al. 2014). In line with this approach, strategies aimed at increasing or retaining members should focus on developing proximity services, developing welcome protocols, permanent contact with local level officials, and so on.

\section{Passive and active approaches to recruitment}

In this context, we observe a predominance of passive approaches to recruitment (including reduced fees for particular groups) instead of more active approaches that entail the development of new services. Two main strategies have been identified in union leaders' discourse regarding organizational change and the need to reach hard-to-organize groups.

The first strategy, aimed at strengthening the connection between the union and society, promotes a modernization of structures, working procedures, communication strategies and services offered to new types of workers and specific groups, paying particular attention to young people. The objective would be to make the union visible and emphasize its role in defending workers' interests in collective bargaining.

The second strategy, based on worries about lost influence and negative attitudes towards unions in a hostile economic and ideological context, is aimed at reinforcing the traditional union working-class identity and at ensuring unions' social influence in the institutional arena. Analysis shows that union leaders regard these strategies as being in conflict with other strategies and find it very difficult to articulate them (Martínez-Iñigo et al. 2012).

\section{Institutional change to promote trade union membership?}

According to some authors, the institutional roots of low membership in Spain suggest that unless there are changes in this dimension, all the trade unions' efforts will have limited success (Lahera 2016). One alternative put forward is to change workplace representation structures. In this way, workers' representatives should be elected directly 
to trade union sections, which, depending on the election results, would exclusively manage negotiations and conflicts in the workplace. On this basis, determining union representation should be based on a combination of election results and the number of members. Also, collective bargaining should be transformed from general effectiveness (automatic, erga omnes extension) to limiting effectiveness to the signatory parties, at least in conventional units below sectoral level. All this would enable the union, finally, to fund itself better through membership fees and thus make it less dependent on public subsidies (Lahera 2016). These changes would help to increase trade union affiliation; workers would have an incentive to join a union in order to enjoy the benefits of a collective agreement and the union could attract members, thereby gaining power and representativeness.

The most representative trade unions at national level (the CCOO and the UGT) are critical of these mechanisms. Even though they agree on the negative incentives provided by the institutional context for union membership, they nonetheless believe that institutional change would not be beneficial for the working class as a whole. They favour an inclusive system that allows all workers to be represented and covered by collective agreements, at the expense of lower union membership, instead of a system in which nonunionized workers would be left out and membership would be higher.

\subsection{Representativeness and Membership of Employer Organizations}

Even though it has received less scholarly and media attention, the representativeness and membership of employer organizations are crucial, for several reasons: first, because as shown in the 'varieties of capitalism' literature - employer organizations are central to socio-economic coordination (Hall and Soskice 2001). Secondly, because employer organizations are also key to coordinating collective bargaining and ensuring high levels of coverage.

In the case of Spain, there is also less public debate around representativeness and membership of employer organizations compared with trade unions. There is one major employer confederation, Confederación Española de Organizaciones Empresariales (CEOE), which represents all types of companies and sectors. Within the CEOE is the CEPYME, a confederation representing the interests of small and medium-sized companies. Historically, large companies have played a leading role within the CEOE. In a country dominated by small businesses, this has created some tensions. In 1980 there was an organizational merger of the CEPYME into the CEOE to try to address this. The CEPYME has accordingly acted as a counterbalance to the interests of big business within the CEOE.

Employer organizations do not have election processes similar to those that determine the condition of more representative trade unions, and there are no reliable, publicly available data on membership of employer organizations. It is self-reported by employer organizations without a standard methodology. Even though the law establishes a priori clear criteria to determine which employer organizations are considered most representative, there are aspects that remain vague (Miñarro 2016). According to the Labour Code, employer organizations that cover 10 per cent of companies will be able negotiate sectoral agreements, provided that they employ the same percentage of workers within the functional and geographical scope of the collective agreement. Moreover, employer organizations whose 
members cover at least 15 per cent of the affected workers within the functional and geographical scope of the collective agreement will also be able to negotiate sectoral collective agreements. In those sectors in which no employer organizations meet these criteria, those organizations that cover 10 per cent of companies affiliated at national level, or at least 15 per cent of companies or workers at regional level will be able to negotiate.

The criteria for determining the most representative employer organizations are, accordingly, more vague and flexible compared with those affecting trade unions. Generally, determination of the most representative employer organizations to negotiate a collective agreement is not based on objective numbers - either of member companies or workers covered (owing to the difficulties involved in obtaining the data) - but on mutual recognition among all parties involved in the negotiations. However, for new employer organizations that claim to meet the criteria and therefore to be involved in signing the collective agreement, this mechanism introduces a bias, as it obliges them to prove they meet the criteria but does not do so for those that have already been mutually recognized by all the other parties. Thus, in a context of unity among employer organizations, mutual recognition can work without major problems, but in a context of fragmentation of employer representation, it can be a source of conflict, as shown by the Italian case (Pensabene 2019).

As noted by Lahera (2019) the system determining the most representative employer organizations has a strong bias in favour of large companies, which confer a high volume of employment and representativeness on their employer organizations, while marginalizing small and medium-sized enterprises. The representativeness of employers thus revolves around a criterion that deviates from the reality of an economy based on small and medium-sized companies, which must apply agreements with little connection to the negotiators. The power of the most representative employer organizations tends to be concentrated in large companies, which may be leading to the rise of new employer organizations at regional or local level as a counter-power to the existing employer organizations. This can be observed in the Basque country and Catalonia, but also in Andalucía (Miñarro 2016).

The only survey that tries to capture the number of companies affiliated to employer organizations is the Encuesta Anual Laboral. Table 13.1 contains the percentage of member companies according to company size. There is an overrepresentation of large companies in employer organizations compared with smaller ones. Moreover, there has been a clear decline in the number of companies affiliated over the period, considering all company size groups. Unfortunately, we do not have data on the number of workers covered. Table 13.1 suggests that the percentages of workers in companies affiliated to employer organizations are higher.

\section{THE STATE'S ROLE IN INDUSTRIAL RELATIONS AND THE AUTONOMY OF THE SOCIAL PARTNERS}

\subsection{Statist Industrial Relations in Spain?}

The most salient feature of the system inherited from the Franco dictatorship was its heteronomy, whereby the state maintained control of employment relations through 
Table 13.1 Percentage of companies that are members of an employer organization, Spain, 2013-17

\begin{tabular}{lccc}
\hline & 2013 & 2015 & 2017 \\
\hline Total & 28.5 & 24.7 & 20 \\
5 to 9 employees & 21.3 & 19.6 & 14.8 \\
10 to 49 employees & 35.3 & 28.1 & 23.7 \\
50 to 249 employees & 46.9 & 46.5 & 38.4 \\
250 to 499 employees & 55.6 & 55.4 & 48.4 \\
More than 499 employees & 67.1 & 65.2 & 55.0 \\
\hline
\end{tabular}

Source: Encuesta Anual Laboral.

extensive regulation of collective bargaining, as well as employees' rights and working conditions, through the Ordenanzas Laborales (Labour Ordinances), covering issues ranging from pay scales to skills. The whole regulatory edifice was built around the standard form of employment (full-time, permanent, blue-collar male industrial workers) and provided strong protection for this group compared with others.

The democratic transition brought some changes aimed at opening up new spaces for autonomous regulation by employers and unions. However, the legacy of Francoist authoritarian corporatism was still visible in some aspects of the industrial relations framework created in the early years of democracy, as state intervention through statutory regulations remained pervasive (Del Rey and Falguera 1999). The strong institutionalization of the industrial relations system can be observed at all levels and dimensions of the system, and consists of intensive legal regulation; from the rules on the representativeness of social partners, to the erga omnes extension of collective bargaining, trade union workplace elections or the articulation between levels in the collective bargaining structure. Legal regulation of collective bargaining means that the Spanish system is far from voluntarist in nature, as confirmed by the 1980 Labour Code that set a substantial floor of procedural and substantive state regulation. The objective was to assist in the development of collective bargaining to weak social partners (Valdés 1995).

Even though a high degree of institutionalization with strong regulatory intervention by the state has often been presented as a strength (as it contributes to institutional stability), it is also one of the weak points of Spain's industrial relations. The regulation of processes and contents of collective bargaining reduces the room for manoeuvre of social partners and hence, their autonomy. Moreover, it can be an obstacle to developing innovative approaches in collective bargaining, such as introducing new issues in collective agreements. Similarly, the high degree of regulations provides incentives for actors to rely on judicial mechanisms for conflict resolution, therefore hindering the development of out-of-court mechanisms and triggering higher levels of industrial conflict (Rodríguez et al. 2016). Summing up, intensive regulation of industrial relations can have a positive impact in relation to institutional stability, but can also become an obstacle for the system to adapt to new challenges.

Since the early 1980s, the governance of industrial relations in Spain has been characterized by two partially contradictory movements (Molina 2007): first, by an increase in the autonomy of the social partners in regulating employment relations; and second, by 
episodes of unilateral state regulation, especially in crisis periods. The contrast between these two long-running trends became particularly clear during the Great Recession (see the following section).

\subsection{Stronger State Unilateralism in the Crisis ...}

Even though all actors interviewed agree on the stronger role of state unilateralism during the crisis, they maintain slightly different perspectives on the impact of reforms. As regards trade unions, they consider the reforms to industrial relations pushed unilaterally by governments in 2011 and 2012 as largely unnecessary and as having a strong negative impact on working conditions, as shown by the internal devaluation and the increase in inequalities (Rocha 2014). By contrast, while considering that these reforms should always respect social partners' autonomy, employer organizations evaluate their impact positively, despite not agreeing with all aspects.

In contrast to collective bargaining reforms in the $1990 \mathrm{~s}$ and $2000 \mathrm{~s}$, whose aim was to enhance autonomy by opening larger spaces for collective self-regulation and companylevel bargaining under the umbrella of industry-level agreements, these spaces were reduced in the unilateral reforms introduced in the Great Recession and, in particular, by the 2012 reform. With the crisis, there has been an extension of opt-out clauses, accompanied by conferring greater unilateral decision-making capacity on employers. The ultimate aim of these changes is to enhance competitiveness and labour market flexibility by increasing the adaptability of collective bargaining to the conditions of firms and sectors.

The weakening of collective autonomy and self-regulatory capacity can also be observed in conflict resolution mechanisms. In the 1980s, the detailed body of statutory legislation made the judicial channel the default mechanism for collective conflict resolution. Sectoral and company-level agreements were endowed with the capacity to settle disputes, but this mechanism was seldom used and remained largely ineffective. An important change occurred in 1996 when the social partners signed the Inter-confederal Agreement for Out-of-Court Conflict Resolution (Acuerdo Interconfederal de Solución Extrajudicial de Conflictos Colectivos, ASEC). This bipartite peak agreement was not only aimed at further developing extrajudicial mechanisms, but it also created the Interconfederal Service for Mediation and Arbitration (SIMA). This institution is in charge of organizing and monitoring the development of extra-judicial mechanisms, and participates mainly in mediation and arbitration cases. This agreement has subsequently been renewed by the social partners, revealing a strong commitment towards developing extrajudicial mechanisms. Compulsory state arbitration was limited to conflicts that affected basic community services or the development of trade union elections.

Changes introduced during the economic crisis have gone in different directions. The 2011 reform made recourse to mediation compulsory in cases of disagreement, regarding either the renewal of the collective agreement or implementation of mechanisms for internal flexibility. If no agreement is reached under mediation, compulsory arbitration within the SIMA is used to resolve any disagreement. In contrast, the 2012 reform established the possibility for compulsory arbitration by the Advisory Commission on Collective Agreements (Comisión Consultiva de Convenios Colectivos) in cases of conflict regarding opting out of company-level agreements. 
As to wage-setting, developments during the economic crisis also show the tensions existing between collective self-regulation and state regulation. In the 1980s there was a clear move towards the consolidation of autonomous wage-setting in the private sector based on peak-level cross-sectoral coordination. Even though the state was an important actor behind the wage pacts of the early 1980s, the conflict between trade unions and the Socialist government hindered any attempt at replicating incomes policy agreements. After some years of uncoordinated wage bargaining and decentralization, wage-setting since the late 1990s has been characterized by genuinely autonomous coordination through peak bipartite cross-sectoral agreements, signed by the most representative trade unions and employer organizations.

Finally, an additional impact of the crisis and austerity measures has been a move back to unilateral state regulation of working conditions in the public sector. In 2008 and 2009 wage increases for civil servants were agreed in the General Bargaining Forum. For salaried employees, their wages and wage increases for 2008 and 2009 were negotiated in the 'Second collective agreement for salaried employees 2006-2008' and in the 'Third collective agreement for salaried employees 2009'. These two agreements established that the same increases negotiated for civil servants should be applied to salaried employees. In contrast, from 2010 until 2015, pay increases for public sector employees were imposed unilaterally.

In summary, the above developments show the fragility of collective self-regulation in a country with a statist industrial relations tradition under the external pressures of economic adjustment. Despite the consolidation of autonomous collective bargaining and the reduction in conflict rates, the state still plays the role of coordinator and regulator of last resort, as became clear in the recent economic crisis.

\section{3 ... Which Remains Strong in the Post-crisis Period}

Even in a context of economic recovery and with a left-wing government since 2018 that has made clear its commitment with social dialogue, the social partners have expressed their discomfort with some decisions, including the unilateral increase in the minimum wage for 2019 (see Box 13.1), the unilateral approval of a law for registering working time (see Box 13.2) or their limited involvement in the most recent phase of the European Semester process. The social partners consider that governments of different colours have often intervened in policy issues that should be dealt with and decided through social dialogue. To a certain extent, these developments show the fragility of collective self-regulation in countries with statist traditions under pressure of economic adjustment.

The social partners interviewed provide several explanations for the persistence of state unilateralism in the post-crisis period. First is the unstable political situation. The fragmentation in the political party landscape has made it very difficult to reach stable majorities in Parliament. As a consequence, there have been four general elections since December 2015. In June 2018, the right-wing government lost a no-confidence vote and a new left-wing government, headed by Pedro Sanchez, was appointed that nonetheless failed to achieve the necessary support after the elections held in April 2019. After new elections in November 2019 delivered similar results, negotiations delivered - only in January 2020 - a coalition government with the left-wing party Podemos. The social 


\section{BOX 13.1 THE INCREASE IN THE STATUTORY MINIMUM WAGE FOR 2019}

At a meeting of the Council of Ministers held in Barcelona on 21 December, the executive approved a 22.3 per cent increase in the minimum wage as of 2019 , from $€ 735.9$ to $€ 900$ per month, or $€ 12$ 600 per year (based on 14 monthly payments). This is the largest increase in the minimum wage since 1977.

The increase was negotiated between the Socialist government and the left-wing party Podemos as part of their agreement for the 2019 budget. The government justified the move as needed to converge with the EU average minimum wage in the context of economic growth. It will also serve to improve the general condition of the economy, while helping to prevent in-work poverty and encouraging more dynamic wage growth. More specifically, this increase is in line with recommendations made by the European Committee of Social Rights to set the minimum wage at 60 per cent of the median wage in the economy and will contribute to meeting the objectives of the 2030 Agenda. The government also expects this increase to have a positive impact on domestic demand and lead to an increase in tax revenues through social security contributions.

Contrary to standard practice, the increase in the minimum wage has been set unilaterally, without negotiations with trade unions and employer organizations, although they were consulted about it. While trade unions have welcomed it, employer organizations have been very critical of the increase, as they feel it will weaken jobs and become an obstacle to job creation.

\section{BOX 13.2 COMPULSORY REGISTRY OF WORKING TIME: BETTER WITH SOCIAL DIALOGUE}

The registration of working hours was long demanded by the Labour Inspectorate, which warned that it did not have sufficient tools to prove abuses of working hours, such as unpaid overtime and fraudulent part-time contracts (for which employees have a reduced working day on paper, but they must work more hours).

In March 2019, and after informing the social partners, the government approved a package of measures designed to improve the position of particularly vulnerable groups in the labour market and to combat precarious work (Royal Decree 8/2019).

One measure was a new regulation on registering employees' working time in an effort to curb the abuse of unpaid overtime by companies. The regulation on registering working time gives companies two months to record the start and end times of the working day for each employee. These records must be kept for four years and be accessible to employees, their representatives or the Labour Inspectorate.

The implementation of the registration system is left to collective bargaining between companies and trade unions or, failing that, the discretion of the employer.

This regulation has received strong criticisms from employers, but also from trade unions. As regards, employers (CEOE), they complain about the form and content of the reform. More specifically, they consider that this is a terrain for social dialogue, not for the government's unilateral regulation. Doing it unilaterally has prevented the regulation from being polished to make it easily applicable by companies. Currently, there is a great deal of uncertainty about how to apply it, and companies are adopting very different criteria for measuring things such as rest breaks, lunch time, and so on. In relation to the content of the reform, employers consider that it introduces additional elements of rigidity instead of the flexibility required by the labour market. More importantly, the CEOE believes that in some companies this new obligation is giving rise to a different reality from what might have been expected, which was the control of illegal or abusive overtime. In this way, many companies are realizing that once they make the record, the employees owe them the hours. 
The most representative trade unions (the CCOO and the UGT) think that this reform is a step in the right direction in tackling an important problem of the Spanish labour market, namely, the abuse of part-time contracts and, more generally, non-payment of overtime. However, they also believe that it falls within the domain of the social partners and should be addressed and regulated through social dialogue. They also think that had it been negotiated with the employers, the reform would have been different.

partners agree that this situation, with a series of acting governments, has obstructed social dialogue, as they could not commit to substantial reforms. Moreover, governments have been more concerned with forging alliances with other political parties than in engaging in social dialogue.

Secondly, the trade unions consulted also mentioned the fiscal straitjacket of the euro as a further impediment to engaging in meaningful social dialogue. According to them, the financial stability rules limit governments' room to manoeuvre, therefore making it more difficult to reach agreement on some issues. In this context, the trade unions have also shown disappointment with their role in the European Semester process, which is constrained by a very tight schedule and does not allow them to fully incorporate the social partner's views.

\section{SOCIAL PARTNERS, DIGITALIZATION AND INDUSTRIAL RELATIONS: WHAT ROLE FOR SOCIAL DIALOGUE?}

The growth of digitalization, automation and the emergence of platforms are diverse manifestations of the technological revolution that is currently taking place throughout the world, and is rapidly transforming the structure and governance of companies as well as the labour market. The algorithms behind these processes are increasingly important as determinants of social order, work organization and business decisions (FernándezMacías 2018; Foerster-Metz et al. 2018). Analysing the impact of digitalization therefore entails studying the new set of economic relationships that are arising from continuous and widespread datafication, the application of digital intelligence through digital networks, and the implications of this change for social and business structures.

Within the framework of all the social processes linked to the new technologies, and specifically in the labour market, in this section we adopt a narrow approach and focus on the platform or gig economy. Platforms are open and dynamic Internet spaces that offer products and services, and intermediate between supply and demand. Thus, the platforms have a significant impact, not only on prices, but also on the manner of providing the service, the organization of work and the way in which consumers interact with their services and suppliers. Work on platforms, or gig work, refers to those services developed by independent workers who depend on one or more intermediary platforms, to which they are connected by a smartphone or an application. These workers are generally underpaid (sometimes less than the national minimum wage), can be 'deactivated' at any time, have no protection through collective bargaining, and lack any of the work-related rights that workers enjoy when classified as 'employees' (Hawley 2018, p. 8).

The digital economy is currently the focus of public policy-makers. Although we do not have precise estimates, we can say that we are experiencing a substantial transformation 
(Fernández Macías 2018) which is affecting a growing number of sectors and workers. Thus, the importance of these processes for national and supranational labour and markets cannot be ignored by regulators.

The rapid advance of the digital economy and, in particular, the platform economy in the EU has generated increasing pressure from different actors for governments to act quickly (Maselli et al. 2016). Governments are being asked to regulate to protect workers and (traditional) companies that compete with the platforms, emphasizing the need to establish a level playing field and appealing not only to fair competition, but also to maintaining Social Europe. In the face of these voices, however, there are others who advocate greater caution, since excessive and hasty regulation could hamper innovation (Lenaerts et al. 2017; Nooren et al. 2018).

Despite the growing voices calling for regulation of the platform economy, to date few steps have been taken, with significant variation in the degree and type of regulation across EU countries. This is also the situation in Spain, where no regulation has been adopted thus far and the process remains largely within the legal realm (see Box 13.4 in section 6 of this chapter). There are a number of reasons for this. On the one hand, this is part of the very essence of the platforms, which were born in a legal vacuum and have the generally explicit objective of avoiding regulations. Second, there is the perception, encouraged by the platforms, that as their activities represent a completely new business model arising from rapid technological change, they should not be treated in the same way as existing economic activity (Garben 2017, p. 3). Finally, the greatest difficulty affecting its regulation is that some aspects of the operation of online platforms do not fit easily into pre-established regulatory categories (Munkøe 2017).

The impact of the digital economy on industrial relations is a controversial topic in Spain. Nonetheless, the interest among trade unions and employer organizations has not yet been reflected in social dialogue outcomes or collective bargaining. The interviews have revealed two topics on the agenda of the social partners in relation to the impact of digitalization on employment relations: first, the use of digital mechanisms and tools for workplace monitoring and surveillance; and second, the regulation of platform workers.

\subsection{Social Dialogue, Digital Monitoring and Surveillance}

One of the most important impacts of the digital economy on employment relations is the use of new technologies that allow employers to collect large amounts of data and information on employees, tasks carried out and their performance. This raises a number of issues in relation to the use and ownership of this data. The most controversial aspects concern their use in monitoring employees and assessing their performance.

The role of collective bargaining in regulating the use of digital mechanisms for monitoring and surveillance is still limited, as acknowledged by the interviewees. The policy debate in relation to workplace monitoring has moved to data protection and the new regulation on registering working time (see Box 13.2), which obliges employers to maintain a detailed record of working time for all employees with the objective of reducing abuses of unpaid overtime. In relation to data protection, in 2015 the Spanish Agency for Data Protection produced a handbook for data protection in employment relations (AEPD 2015), containing recommendations on companies' use of employees' data and 
information, including data gathered through surveillance mechanisms. More recently, the UGT published a document containing guidelines for collective bargaining in relation to data protection and guaranteeing digital rights (UGT 2019). In this document, the UGT demands that the role of collective agreements in defending workers' rights be strengthened in relation to data use. The union asserts that the inclusion of protection clauses in collective agreements has an important pedagogical and formative role as a regulator of the necessary protection of employees' right to the protection of their personal data, and the guarantee of specific digital rights.

A digital right discussed, but not yet regulated, is the digital disconnection right. Since 2017 there has been a growing debate among the Spanish social partners and political parties on the possibility of allowing workers to disconnect their digital devices (primarily mobile phones and computers) when their working day ends or during rest breaks. In January 2019, the Ministry of Employment suggested that there should be a national debate on these issues through social dialogue. The Socialist Party and trade unions are strongly in favour of regulating the right to digital disconnection outside working time as there is a lack of relevant legislation, while there has been an increase in symptoms of stress and burnout associated with the continuous use of digital mechanisms beyond working hours. However, CEOE has suggested that there are some sectors in which applying digital disconnection might not be feasible, in which case regulating it by law would impose unnecessary rigidities on companies.

In 2018, the UGT in Catalunya produced a detailed analysis of the relationship between new technologies and workers' privacy rights (Ezquerra 2018). In this document they reiterate the need for the employer's use of technological devices for monitoring purposes in the workplace must be agreed with the workers and adapted via collective bargaining. In its Digital Plan for 2025, the main employer organization, the CEOE, makes a series of proposals in relation to the digitalization of the economy, but nothing is mentioned about workplace monitoring and surveillance (CEOE 2019). However, there is significantly less debate around the use of digital mechanisms and devices at the workplace for monitoring purposes. In fact, this topic has not yet entered bipartite social dialogue and is present only to a limited extent in collective bargaining.

\subsection{Platform Economy and Platform Workers}

\section{Extension of the digital economy in Spain and the challenges posed to the labour market}

The second important challenge posed by the digital economy, and its manifestation in platforms, is the extension of new forms of organization and employment. This is probably the most disruptive aspect of the digital economy in relation to the labour market, as it implies a reconfiguration of traditional employment relationships. Even though it is difficult to quantify the extension of platform work, a number of surveys have suggested that Spain has one of the highest incidences of platform work in the EU (Pesole et al. 2018).

Several factors may explain the stronger incidence of the platform economy and platform work in Spain (Rocha 2017). First, Spain has a high unemployment rate, in particular high youth unemployment. The use of online platforms is more intense for younger people, owing to their greater familiarity with digital technologies and environments. In a situation in which it is difficult to find a job, and many of the jobs that exist are very 
precarious, participation in this type of platform is an alternative to unemployment, and in some instances, an alternative to other jobs. Studies agree on the youthful profile of crowd and platform workers, and the use of these platforms as an alternative means of obtaining income in otherwise bleak circumstances (De Stefano 2016). Crowd workers tend to fall passively into this type of employment rather than it being a way of improving their labour market situation.

Secondly, an economy whose competitive model is based on low costs (including wages), will have more incentive to develop this type of platform since it introduces greater competition among potential service providers, and therefore the development of business models based on price/cost competition. The reduction in the cost of the service, either for individual consumers or for companies, can therefore favour crowdsourcing.

\section{Governing platform work in Spain: from judicialization to social dialogue?}

Since its emergence and extension, there has been a growing debate on whether to regulate the digital economy in general, and the platform economy in particular. This debate is polarized between supporters and opponents of regulation (Codagnone and Martens 2016). Those who defend regulation argue that it is necessary to guarantee the protection and safety of consumers, avoid social dumping (Dittrich 2018) and guarantee fair competition, while others argue that regulation of the negative effects would be more expensive than those effects themselves (Allen and Berg 2014). Although there is a growing consensus that government action is required, the challenge lies in addressing the phenomenon in a way so that the negative impacts of the platform economy can be limited, while enabling opportunities to be seized (Maselli et al. 2016). In particular, those who advocate greater caution in regulation emphasize that the main objective of the new digital governance must be to foster innovation and development, and its regulation must be sufficiently inclusive and prudent while the platform economy is still at an early stage.

In relation to the labour market impact and regulation of platform work, there are several aspects that cause concern among the social partners and therefore justify regulation. This includes the imposition of a commercial relationship between the platform and its service providers, who are treated as independent and thus denied the guarantees of an employee or, even, a self-employed worker (De Stefano 2016; Kuhn 2016). As stated in Eurofound (2018), of all the transformations that the digital economy entails, its labour market impact poses important challenges to governments and the social partners. Of particular concern in this regard is the extension of contractual relationships that evade labour regulations, although many issues are subject to regulation in market and employment relationships (Munkøe 2017, p. 43). Whether or not workers on platforms that have traditionally been framed within the collaborative economy should be considered employees or freelancers is a key issue, as employees enjoy rights and employers have tax obligations that do not apply to massive outsourcing (Todolí-Signes 2017). To the extent that a platform worker is not considered a dependent worker, they lose particular social and labour rights, both individual (unemployment protection, training, and so on) and collective (representation and collective bargaining) (Lenaerts et al. 2017).

Similar concerns were raised by the social partners interviewed in Spain. Their main responses to the platform economy are summarized next. 


\section{Organizing platform workers: challenges and strategies to creating a collective identity}

The organization of platform workers themselves is the first response. The protest and strike actions carried out by Spanish riders took place after actions in other European countries, including the UK and the Netherlands. Several organizations representing riders have been created in recent years, but the first and most important one is 'Riders x Rights' (Riders x Derechos). This organization brings together and represents riders from various platforms, including Glovo and Deliveroo. Through protest actions and strikes, these workers asked for improvements in their working conditions, including setting a minimum number of hours of work per week and an increase in hourly deliveries, with the aim of improving their income and achieving greater stability.

Organizing platform workers, whom platform companies refuse to acknowledge as employees, is aimed at building a collective identity. Although this organization has been carried out autonomously, the largest unions are becoming more sensitive to the problems of these workers. Thus, the UGT has launched a platform to collect demands and complaints from platform workers (Tu Respuesta Sindical Ya). The organization of these workers is a necessary condition for better regulation of their working conditions. More specifically, their organization requires overcoming the fragmentation and individualization imposed by digital platforms, and developing forms of collective action to defend their common interests. Even though their circumstances make organizing these workers very difficult, the use of technology and, in particular, social networks, can paradoxically - be very effective (Aloisi 2015).

\section{Judicialization of the conflict around platform workers}

To date, the main strategy followed by the most representative trade unions in relation to the platform economy and its workers is to judicialize the conflict. For the unions, this is a response to (1) the difficulties involved in making progress through social dialogue owing to the political situation, and (2) the uncertain legal position of platform workers, who are not considered employees, which makes it difficult for the trade union to organize them.

The most representative trade unions have thus focused their efforts on achieving legal recognition of a dependent employment relationship for platform workers. For this reason, they have helped platform workers to file complaints before the Labour Inspectorate and the Social Courts. The trade union officials interviewed are confident that this strategy will result in judgments that oblige platforms to recognize an employment relationship with their workers. They note that there have already been some early rulings in this direction, although it may still take some time until the superior judicial instances adopt a firm policy in this regard and unify the jurisprudence. Particularly relevant were the first court case on digital delivery companies (in this instance, Deliveroo), in December 2017, in which the Labour Inspectorate concluded that food distributors are not self-employed, and the recent judgment by the Madrid High Court against Glovo (see Box 13.3). In both cases, although the contract between the platform and the riders stipulates that the latter are self-employed, the Courts ruled that this is in fact a dependent employment relationship. 


\title{
BOX 13.3 RULINGS ENDORSE EMPLOYMENT RELATIONSHIP FOR RIDERS OF DELIVEROO AND GLOVO
}

\begin{abstract}
A judgment in 2018 by the Social Affairs Court of Valencia ruled that Deliveroo riders are dependent workers, forcing the company to reinstate or compensate a worker who had been dismissed. The company was sued by a rider who had received daily average remuneration, excluding taxes, of $€ 28.49$. The contract signed with the company indicated that the rider would act 'at all times as an independent contractor' and would not be considered an 'agent, employee or partner of the company', and set the amount that would be received (€3.38 per delivery) and how the deliveries should be carried out. The worker was then dismissed without receiving any compensation.

The ruling declared the dismissal of the worker to be unfair and established, for the first time, that there was an employment relationship between Deliveroo and the rider. This judgment endorses the position of the Labour Inspectorate of Valencia made in December 2017, according to which, riders cannot be considered self-employees or independent workers. The judgment came amid growing interest and concern about work in the platform economy and the extension of new forms of employment, including crowd employment, facilitated by technology. This is the first time a ruling has rejected the idea, promoted by platforms, that these workers are merely service providers and do not have an employment relationship.

Moreover, in November 2019, the Social Section of the Superior Court of Justice of Madrid failed that the riders of Glovo are bogus self-employed. The 17 judges involved in this sentence achieved uniform criteria in this case that contradict and annul a previous ruling of Social Court Number 17 of Madrid that in January had endorsed the company's business model against a rider who had been fired.

Now the Madrid Court has partly upheld the complaint made by the rider that the contractual nexus comes under regular labour law; that is, riders cannot be considered economically dependent autonomous workers (trabajadores autónomos económicamente dependientes, TRADE) because it is not true, according to the magistrates, that they carry out their tasks with 'total freedom' and because they work with 'other people's means' on the basis of the digital platform.
\end{abstract}

\section{CASE STUDIES}

\subsection{Case Study 1: Governing the Digital Economy: The Role of Social Dialogue and Collective Bargaining}

Trade unions, employer organizations and the government agree on the need to move beyond the current judicialization of the conflicts affecting platform workers and achieve a new equilibrium releasing these workers from the current uncertainty in relation to their status. However, there are marked differences concerning how to reach this goal. Some actors support the enactment of new regulation, adapting existing legal instruments to the needs of the platform economy. Others find that there is no need to regulate (as this would imply an erosion of existing rights) and that collective bargaining can also be a valid mechanism for protecting platform workers.

\section{Digital TRADE (economically dependent autonomous workers) and the regulation of platform work through social dialogue}

The interviews have revealed a common interest on the part of both employers and trade unions in regulating the platform economy, and in particular the working conditions of platform workers, in order to ensure a level playing field for all companies and avoid 
unfair competition. The current situation is characterized by uncertainty when it comes to qualifying the relationships between digital platforms and service providers (platform workers). The contradictions that arise in judicial rulings on the legal status of these workers make it reasonable to demand regulations aimed at clarifying the nature of their relationship to digital platforms.

However, there is no consensus among the social partners on how to achieve this goal. Even within employer organizations, different positions have been identified. In March 2019, the Asociación de Trabajadores Autónomos (ATA, Association of Autonomous Workers), a hybrid between a union and a business association that organizes and represents the self-employed, and is a member of the main employers' confederation, the CEOE, launched, together with ADIGITAL (Asociación Española de la Economía Digital, Spanish Association for the Digital Economy), a proposal to establish the category of 'digital TRADE' aimed at platform workers.

The concept of economically dependent self-employed (or autonomous) worker falls between employment and self-employment. It refers to those who do not correspond to the traditional definition of employee since they do not have an employment contract as dependent employees. However, although from a formal point of view they are selfemployed, they are also economically dependent on a single employer for all or much of their income (according to Spanish law, more than 75 per cent of their wages, either as a paid employee or as a businessperson). This special relationship is strongly regulated and needs to be carefully defined in a written contract, which should also specify whether it is permanent or temporary.

According to the ATA and ADIGITAL, the TRADE category provides a good starting point for developing a new regulation that fits the characteristics and needs of workers in the platform economy. In a recent document, ADIGITAL (2019) presented a proposal to regulate in this direction, taking France as an example. The idea is to open up a debate on this issue and define the digital TRADE. The proposed regulation is based on two pillars: the first establishes a criterion in terms of the relevant labour regime and the second focuses on ways in which the TRADE model can be improved. In relation to the first aspect, the requirement is that a digital channel is the only means of offering the platform's services, for contracting and paying for them, and for formalizing the contract between the worker (termed the user provider) and the digital platform. The proposal considers three additional requirements: first, these workers must be able to decide independently how much work they will take on and how to organize it; second, the relationship must be non-exclusive; and third, instruments or tools must be provided for carrying out the work. Autonomy concerning decision-making is particularly important as that has been the criterion used in some judgments and by the Labour Inspectorate to define the relationship between platform and worker as one of dependency. ${ }^{1}$ According to this interpretation, the platform maintains control over the organization of work as a prerogative of the employer. For this reason, a platform worker should be considered an employee of the platform. ADIGITAL's proposal specifies the conditions that determine whether a worker is truly autonomous, namely if they, as service provider, can freely choose the form, schedule and days on which they want to work, without penalties.

However, the Labour and Social Security Inspectorate warns that most of the judgments coincide in asserting the existence of an employment relationship between riders and platforms. Moreover, they do not see the need to make an ad hoc regulation for 
platform work, as this would probably entail the erosion of existing rights. In their view, platform work could be brought under existing regulations.

The lack of consensus among employers could be seen when in September 2019 the ATA withdrew its support for the digital TRADE proposal. According to the ATA, this move was a response to the need to wait for clear judgments and solid jurisprudence on the categorization of platform workers. Moreover, they also think it is important to reach a common position within the employers' confederation in order to enhance their bargaining position and avoid organizational tensions.

It is also interesting to note that another important association for the self-employed, the Unión de Profesionales y Trabajadores Autónomos (UPTA) maintains a different position, which is close to the UGT's, that there is no need to issue new regulations on platform work because platforms and their activities could be adapted to the current legislation in Spain.

Finally, the acting Minister of Employment and Social Security, Magdalena Valerio, has already expressed her intention to increase the protection of riders and platform workers more generally. The caretaker government has already made clear its intention to draft a new Labour Code to adapt regulations to the new technological and social environment. However, any new regulation will come out of tripartite social dialogue.

Even though they disagree on the best formula for regulation, employers and trade unions do agree that this should be one of the top priorities for social dialogue, but the current political uncertainty is a major impediment to progress.

\section{Regulating platform work through collective bargaining: food delivery in Spain}

The main strategy pursued by the most representative trade unions in Spain, the CCOO and the UGT, is to incorporate platform workers in existing collective agreements so that their working conditions are governed by its provisions, thereby assimilating them to those of workers performing similar tasks in non-platform companies. In this endeavour, the trade unions have the support of the main employer organizations in the sector, since they share an interest in limiting social dumping through the use of platforms and ensuring a level playing field.

A major achievement here was the extension in March 2019 of the fifth sectoral collective agreement for restaurants and catering (ALEH-V) until December 2020. With this extension, the main employers and trade unions in the sector brought in home food delivery workers 'on foot or in any type of vehicle that does not require administrative authorization established by transport regulations, as a service provision from the establishment or commissioned by another company, including digital platforms or through them'.

The inclusion of riders in the collective agreement categorizes them as workers in the hospitality sector, thereby ending the legal uncertainty that afflicted them as independent workers. According to the CCOO, this collective agreement constitutes an important landmark and points the way for other collective agreements to improve the working conditions of platform workers. This union indicates that other collective agreements can, along the lines of the ALEH-V, regulate the occupational category, wages and functions of platform workers in that sector. Moreover, these workers are also protected in case of subrogation, succession or replacement of businesses with concession catering services in public places such as airports and railway stations, either as a single concession, or in cases of segregation in various concessions. 
Employers in the sector have also welcomed this extension as a way of guaranteeing that all businesses in the sector play by the same rules. However, ADIGITAL, the association that groups the companies of the digital economy, has criticized this agreement. First, the lack of involvement of any worker or worker representative in the negotiation of this extension does not make much sense. Secondly, they note that the mere recognition of an employment relationship in a collective agreement (as the ALEH-V does) does not mean that digital platforms fit this regime. Some important members of ADIGITAL such as Glovo and Deliveroo, have not applied the agreement because they consider that a collective agreement is not applicable to the self-employed. Both platforms maintain that there is no employment relationship between the riders and the platform, and that the extension of the ALEH-V further complicates the public debate on platform workers. As previously noted, ADIGITAL insists that the existing regulations need to be adapted to what it considers to be the new economic and social reality, as some other EU countries are already doing.

The trade unions consulted consider that this extension to be the way forward, however, and indicate other collective agreements, such as that in transport and logistics, where they are pushing to introduce similar clauses with the support of the main employer organizations in the sector.

\subsection{Case Study 2: Peak Cross-sectoral Social Dialogue between Unions and Employers Remains Strong}

Despite the problems in relation to tripartite social dialogue during the crisis, bipartite social dialogue between unions and employers has remained very strong. The social partners nonetheless agree on the importance of bipartite cross-sectoral social dialogue as an instrument for governing industrial relations and reaffirming their autonomy vis-à-vis the state. In contrast to tripartite social dialogue, bipartite social dialogue between trade unions and employers has maintained its vitality and, in July 2015, the social partners signed the 'Third Agreement on Employment and Collective Bargaining 2015-2017'. Even though negotiations took longer than expected owing to disagreement on wage increases, the unions and the employers reached agreement on the guidelines for developing collective bargaining in the coming three years. Bipartite social dialogue has accordingly shown greater resilience than tripartite social dialogue, a trend that has already been identified (Molina and Rhodes 2011).

A new agreement was signed in 2018. After several months of negotiations, which broke down on several occasions owing to disagreements between unions and employers on wage increases, in June 2018 a new peak cross-sectoral agreement was signed by the most representative trade union organizations - the CCOO and the UGT - and employer organizations (the CEOE and the CEPYME). The peak-level, inter-sectoral agreement covers wages and collective bargaining until 2020. The social partners are keen for this pact to mark a turning point in relation to the internal devaluation that started in 2010 and led to a decline in wages in real terms. The agreement sets out negotiated wage increases of up to 2 per cent until 2020, with the possibility of an additional 1 per cent increase depending on productivity trends, business performance and levels of absenteeism. It also establishes a base of $€ 14000$ a year for negotiated wages, a clear improvement for the lowest wages, which suffered most in the crisis (see Box 13.4). 


\title{
BOX 13.4 THE ROLE OF SOCIAL DIALOGUE IN INCREASING REAL EARNINGS AND FIGHTING AGAINST LOW WAGES IN THE POST-CRISIS PERIOD
}

\begin{abstract}
Since 2014, the Spanish economy has experienced positive growth rates and the labour market has improved considerably in relation to employment. However, real earnings have lagged behind in both the private and the public sectors of the economy. Governments and social partners have implemented a series of initiatives in order to tackle this situation. The first step consisted of a new framework agreement for working conditions and employment in the public administration, signed between the finance minister and the most representative trade unions in the public sector: the $\mathrm{CSIF}$, the $\mathrm{CCOO}$ and the UGT. The agreement establishes a minimum wage increase of 6.1 per cent for public employees over the period 2018-20 (1.75 per cent in 2018, 2.25 per cent in 2019 and 2 per cent in 2020), and a maximum of 8.9 per cent conditional upon GDP growth and the fulfilment of the budget deficit target for 2020. It is the first time that wage increases for public employees will be linked to macroeconomic performance, with higher wage increases to be paid when GDP growth surpasses 2.5 per cent. Moreover, the agreement means that collective bargaining in the public sector has been restored after several years of unilateral regulation.

The second step consisted of the bipartite peak agreement between trade unions and employers signed in June 2018. With this agreement, the social partners wanted to mark a turning point in relation to the internal devaluation starting in 2010 , which led to a substantial decline in real wages. This pact also puts an end to the deadlock in bipartite peak inter-sectoral agreements for collective bargaining coordination and employment, as the last agreement was signed in 2015 and attempts to negotiate a new agreement have failed since then. The agreement contemplates negotiated wage increases of up to 2 per cent until 2020, with the possibility of an additional 1 per cent increase conditional on productivity, performance and levels of absenteeism. In addition, the agreement also establishes a floor for negotiated wages of $€ 14000$ a year, a clear improvement for the lowest wages, which suffered most in the crisis.

Finally, late in 2018, the government approved a 22.3 per cent increase in the statutory minimum wage to $€ 900$ per month for 2019 , the largest increase in the period since the restoration of democracy. This increase was set unilaterally by the government in December 2018.
\end{abstract}

\section{CONCLUSIONS}

This analysis of practices and cases around three major industrial relations issues has revealed the important role of social dialogue in governing the challenges facing industrial relations in Spain. Social dialogue was abandoned during the Great Recession, but experienced a slow revitalization in the post-crisis period. Even though it has gained some momentum since 2018, the social partners coincide in identifying political instability as a main obstacle to advancing on some of the issues. Moreover, they also converge in the need to reaffirm social partners' autonomy in a context in which unilateral state regulation remains in place, notwithstanding the improvement in economic conditions. The role of bipartite cross-sectoral agreements on employment and collective bargaining signed since the late 1990s constitutes, according to the social partners, the best example of autonomous governance of industrial relations and has become one of the key elements of industrial relations in Spain. Employers have been particularly concerned in recent months about the state regulating unilaterally in key areas, such as the minimum wage and working time register. 
The social partners in Spain face significant challenges in the new world of work and agree on the need to strengthen a number of capacities in order to be able to provide effective responses based on social dialogue. Enlarging the membership base is considered key from the trade union side, as this would not only enhance the input legitimacy of social dialogue, but also help to strengthen other power resources of trade unions. However, no clear strategy on achieving this goal has been identified owing to the institutional context, which the unions view as the main obstacle to boosting their membership. Even though membership is not considered a problem for employer organizations, there are emerging issues in relation to determining representativeness, especially for new employer organizations. On both sides, associational fragmentation and the appearance of new organizations is considered an important challenge from the point of view of membership, representativeness and the governance of industrial relations.

The multi-dimensional character of the impact of digitalization on industrial relations explains why the social partners tend to focus on different elements. For trade unions, the implementation of new technologies that allow employers to collect a large amount of data from employees, poses important challenges in relation to their use for surveillance or disciplinary purposes. Even though existing regulations on data protection and a number of legal judgments already provide some criteria on how to collect and use data, there remain gaps in relation to employers' use of artificial intelligence (AI) or algorithms. Trade unions believe that this should be one of the key issues to be negotiated in the context of tripartite social dialogue. The extension of the platform economy and platform work constitutes another main concern for trade unions, and to a lesser extent for employers. Currently, the quantitative extension of the platform economy remains limited, but the unions have raised the alert about the risks of platformization of the economy if adequate regulations are not introduced. Similarly, some employers have also expressed concern about the unfair competition practised by platforms in some sectors (for example, retail, hospitality and food and restaurants), as they do not comply with existing collective agreements or regulations. In these instances, trade unions and employers are building a shared space for autonomously regulating platform work through social dialogue.

\section{NOTE}

1. Rulings on this issue differ: some assert that the relationship between the rider and the company is a true work contract (judgments of Social Court 6 of Valencia, 1 June 2018 and of Social Court 31 of Barcelona, 11 June 2019), while others find that the special circumstances of this legal relationship mean that it differs from an employment relationship (judgments of Social Court 39 of Madrid, 3 September 2018 and of Social Court 17 of Madrid, 11 January 2019).

\section{BIBLIOGRAPHY}

Agencia Española de Protección de Datos (AEPD) (2015), Guía de Protección de Datos en las Relaciones Laborales, Madrid: AEPD.

Allen, D. and C. Berg (2014), 'The sharing economy. How over-regulation could destroy an economic revolution', Institute of Public Affairs, Melbourne. 
Aloisi, A. (2015), 'Commoditized workers: case study research on labor law issues arising from a set of on-demand/gig economy platforms', Comparative Labor Law \& Policy Journal, 37 (3), 653-89.

Alós, R., P. Beneyto, P. Jódar, O. Molina and S. Vidal (2015), La representación sindical en Españ, Madrid: Fundación 1 de Mayo.

Amable, B. (2003), The Diversity of Modern Capitalism, Oxford: Oxford University Press.

Asociación Española de la Economía Digital (ADIGITAL) (2019), 'Propuesta Normativa en Materia de Trabajo en Plataformas Digitales', accessed 5 November 2016 at https://www.adigi tal.org/media/propuesta-regulatoria-plataformas-digitales.pdf.

Barranco, O. and O. Molina (2014), 'Sindicalismo y crisis económica: Amenazas, retos y oportunidades', Kult-ur, 1 (2), 171-94.

Behrens, M., R. Hurd and J. Waddington (2004), 'How does restructuring contribute to union revitalization?', accessed 22 November 2019 at http://digitalcommons.ilr.cornell.edu/articles/1013/.

Beneyto, P.J., R. Alós, P. Jódar and S. Vidal (2016), 'La afiliación sindical en la crisis. Estructura, evolución y trayectorias', Sociología del trabajo, 87, 25-44.

Calavia, M.A.G. and M. Rigby (2019), 'Las trayectorias de las instituciones laborales españolas ante las recientes presiones económicas: ¿ Cómo quedan los recursos para los sindicatos?', RES. Revista Española de Sociología, 28 (2), 381-99.

Confederación Española de Organizaciones Empresariales (CEOE) (2019), Plan Digital 2025: La Digitalización de la Sociedad Española, report, CEOE, Madrid, accessed 18 August 2021 at https://circulodeempresarios.org/transformacion-digital/wp-content/uploads/Publicaci onesInteres/plan-digital-2025-la-digitalizacion-de-la-sociedad-espanola.pdf.

Codagnone, C. and B. Martens (2016), Scoping the Sharing Economy: Origins, Definitions, Impact and Regulatory Issues, Institute for Prospective Technological Studies Digital Economy Working Paper 2016/01, Joint Research Centre of the European Commission, accessed 18 August 2021 at https://ec.europa.eu/jrc/sites/default/files/JRC100369.pdf.

Culpepper, P.D. and A. Regan (2014), 'Why don't governments need trade unions anymore? The death of social pacts in Ireland and Italy', Socio-Economic Review, 12 (4), 723-45.

De Stefano, V. (2016), 'The rise of the "just-in-time workforce": on-demand work, crowdwork, and labor protection in the "gig-economy", Comparative Labour Law and Policy Journal, 37 (3), 471-504.

Del Rey, S. and M.A. Falguera (1999), 'La regulación y el control públicos de las relaciones individuales de trabajo', in F. Miguelez, and C. Prieto (eds), Las relaciones de empleo en España, Madrid: Siglo XXI de España Editores, pp. 259-72.

Della Porta, D. (2015), Social Movements in Times of Austerity: Bringing Capitalism Back into Protest Analysis, London: John Wiley \& Sons.

Dittrich, P.-J. (2018), 'Online platforms and how to regulate them: an EU overview', Policy Paper No. 227, Jacques Delors Institute, Paris.

Espina, A. (1999), 'El "guadiana" de la concertación neocorporatista en España: De la huelga general de 1988 a los acuerdos de 1997', in F. Miguélez and C. Prieto (eds), Las relaciones de empleo en España, Madrid: Siglo XXI, pp. 375-98.

Eurofound (2018), Employment and Working Conditions of Selected Types of Platform Work, Luxemburg: Publications Office of the European Union.

Ezquerra, L. (2018), 'Nuevas tecnologías en el control de los trabajadores y el derecho a la intimidad del trabajador', accessed 28 October 2019 at http://www.ugt.cat/nuevas-tecnologias-en-elcontrol-de-los-trabajadores-y-el-derecho-a-la-intimidad-del-trabajador/.

Fernández-Macías, E. (2018), Automation, Digitalisation and Platforms: Implications for Work and Employment, European Foundation, Luxembourg: Publications Office of the European Union.

Foerster-Metz, U.S., K. Marquardt, N. Golowko, A. Kompalla and C. Hell (2018), 'Digital transformation and its implications on organizational behaviour', Journal of EU Research in Business, 1, 1-18.

Garben, S. (2017), 'Protecting workers in the online platform economy: an overview of regulatory and policy developments in the EU', European Risk Observatory discussion paper, EU-OSHA. 
Guardiancich, I. and Ó Molina (eds) (2017), Talking through the Crisis: Social Dialogue and Industrial Relations Trends in Selected EU Countries, Geneva: International Labour Organization.

Hall, P.A. and D. Soskice (2001), Varieties of Capitalism: The Institutional Foundations of Comparative Advantage, Oxford: Oxford University Press.

Hawley, A.J. (2018), 'Regulating labour platforms, the data deficit', European Journal of Government and Economics, 7 (1), 5-23.

Jódar, P., R. Alós, P. Beneyto and S. Vidal (2018), 'La representación sindical en España: cobertura y límites', Cuadernos de Relaciones Laborales, 36 (1), 15-34.

Jódar, P., S. Vidal and R. Alós (2011), 'Union activism in an inclusive system of industrial relations: evidence from a Spanish case study', British Journal of Industrial Relations, 49 (s1), 158-80.

Jordana, J. (1996), 'Reconsidering union membership in Spain, 1977-1994: halting decline in a context of democratic consolidation', Industrial Relations Journal, 27 (3), 211-24.

Köhler, H.D. and J. Calleja (2011), 'Retos de futuro para las organizaciones sindicales en España', Gaceta sindical: reflexión y debate, (16), 119-38.

Köhler, H.D. and J. Calleja (2015), “"They don't represent us!” Opportunities for a social movement unionism strategy in Spain', Relations Industrielles/Industrial Relations, 70 (2), 240-61.

Kuhn, K.M. (2016), 'The rise of the "gig economy" and implications for understanding work and workers', Industrial and Organizational Psychology, 9 (1), 157-62.

Lahera, J. (2016), 'Incentivar la Afiliación Sindical', CincoDías, 31 March, accessed 19 November 2019 at https://cincodias.elpais.com/cincodias/2016/03/31/economia/1459450788_727689.html.

Lahera, J. (2019), 'Medir la representación empresarial', CincoDías, 14 June, accessed 11 November 2019 at https://cincodias.elpais.com/cincodias/2019/06/10/economia/1560183767_254754.html.

Lenaerts, K., M. Beblavy and Z. Kilhoffer (2017), 'Government responses to the platform economy: where do we stand?', CEPS Policy Insight No 2017-30/July 2017, Centre for European Policy Studies, Brussels.

Martín Artiles, A. and R. Alos Moner (2003), 'Between decentralisation and centralisation of collective bargaining. The Spanish case', Industrielle Beziehungen, 10 (1), 64-96.

Martínez-Iñigo, D., A. Crego, S. Garcia-Dauder and R. Domínguez-Bilbao (2012), 'Organizational culture as a source of change in trade unions', Employee Relations, 34 (4), 394-410.

Martínez Lucio, M. (2003), 'New communication systems and trade union politics: a case study of Spanish trade unions and the role of the Internet', Industrial Relations Journal, 34 (4), 334-47.

Maselli, I., K. Lenaerts and M. Beblavý (2016), 'Five things we need to know about the collaborative economy', CEPS Essay No. 21, Centre for European Policy Studies, Brussels.

Miñarro, M. (2016), 'Representatividad de las asociaciones empresariales: nuevos tiempos, viejos problemas irresolutos', in R. Quesada (ed.), Treinta años de la Ley Orgánica de Libertad Sindical: perspectivas y retos, Seville: Consejo Andaluz Relaciones Laborales, pp. 237-49.

Molina, O. (2007), 'State and regulation of industrial relations in Spain: old wine in a new governance bottle?', South European Society \& Politics, 12 (4), 461-79.

Molina, O. (2014), 'Self-regulation and the state in industrial relations in Southern Europe: back to the future?', European Journal of Industrial Relations, 20 (1), 21-36.

Molina, O. and F. Miguélez (2013), 'From negotiation to imposition: social dialogue in austerity times in Spain', DIALOGUE Working Paper No. 51, Governance and Tripartism Department, International Labour Organization, Geneva.

Molina, O. and F. Miguélez (2017), 'Post-crisis social dialogue in Spain: the calm after the storm', in I. Guardiancich and O. Molina (eds), Talking through the Crisis: Social Dialogue and Industrial Relations Trends in Selected EU Countries, Geneva: International Labour Organization, pp. $257-80$.

Molina, O. and M. Rhodes (2007), 'The political economy of adjustment in mixed market economies: a study of Spain and Italy', in R. Hancké, M. Rhodes and M. Thatcher (eds), Beyond Varieties of Capitalism: Conflict, Contradictions and Complementarities in the European Economy, Oxford: Oxford University Press, pp. 223-52.

Molina, O. and M. Rhodes (2011), 'Spain: from tripartite to bipartite pacts', in S. Avdagic, J. Visser and M. Rhodes (eds), Social Pacts in Europe: Emergence, Evolution, and Institutionalization, Oxford: Oxford University Press, pp. 174-202. 
Munkøe, M.M. (2017), 'Regulating the European sharing economy: state of play and challenges', Intereconomics, 52 (1), 38-44.

Nooren, P., N. van Gorp, N. van Eijk and R.Ó. Fathaigh (2018), 'Should we regulate digital platforms? A new framework for Evaluating policy options', Policy \& Internet, 10 (3), 264-301.

Pedersini, R. and M. Regini (2013), 'Coping with the crisis in Italy: employment relations and social dialogue amid recession', in K. Papadakis and Y. Ghellab (eds), The Governance of Policy Reforms in Southern Europe and Ireland. Social Dialogue Actors and Institutions in Times of Crisis, Geneva: ILO, pp. 109-26.

Pensabene, G. (2019), 'La Representatividad empresarial en una perspectiva comparada entre Italia y España', Actualidad jurídica iberoamericana, 10 (June), 634-53.

Pesole, A., U. Brancati, E. Fernández-Macías, F. Biagi and I. González Vázquez (2018), Platform Workers in Europe, EUR29275 EN, Luxembourg: Publications Office of the European Union.

Rigby, M. (2016), 'Los recursos del poder de los Sindicatos en España: su examen a traves de la negociación colectiva', Sociología del Trabajo, 87 (10), 7-24.

Rocha, F. (2014), 'Crisis and austerity policies in Spain: towards an authoritarian model of industrial relations', in F. Rocha (ed.) The New EU Economic Governance and Its Impact on the National Collective Bargaining Systems, Madrid: Fundación $1^{\circ}$ de Mayo, pp. 175-204.

Rocha, F. (2017), 'La Digitalización y el Empleo Decente en España Retos y propuestas de actuación', in El futuro del trabajo que queremos. Conferencia Nacional Tripartita, 28 de marzo de 2017, Palacio de Zurbano, Madrid, Iniciativa del Centenario de la OIT, 1919-2019, pp. 259-74, accessed 18 August 2021 at https://www.ilo.org/wcmsp5/groups/public/---europe/--ro-geneva/---ilo-madrid/documents/publication/wcms_615487.pdf.

Rodríguez, C.J.F., R.I. Rojo and M.M. Lucio (2016), 'Austerity and collective bargaining in Spain: the political and dysfunctional nature of neoliberal deregulation', European Journal of Industrial Relations, 22 (3), 267-80.

Todolí-Signes, A. (2017), 'The end of the subordinate worker? The on-demand economy, the gig economy, and the need for protection for crowdworkers', International Journal of Comparative Labour Law and Industrial Relations, 33 (2), 241-68.

Turner, L. and R.W. Hurd (2001), 'Building social movement unionism: the transformation of the American labor movement', in L. Turner, H.C. Katz and R.W. Hurd (eds), Rekindling the Movement: Labor's Quest for Relevance in the Twenty-first Century, Ithaca, NY: Cornell University Press, pp. 9-26.

Unión General de Trabajadores (UGT) (2019), 'Protocolo de Actuación para la Negociación Colectiva. Protección de Datos de Carácter Personal y Garantías de los Derechos Digitales', accessed 5 October 2019 at http://www.ugt.es/sites/default/files/guia-proteccion_de_datos_0.pdf.

Valdés, F. (1995), 'Notas sobre la reforma del marco legal de la estructura de la negociación colectiva', in M. Alarcón and S. del Rey (eds), La reforma de la negociación colectiva, Madrid: Marcial Pons, pp. 119-65.

Vandaele, K. (2019), Bleak Prospects: Mapping Trade Union Membership in Europe since 2000, Brussels: ETUI.

Vandaele, K. and J. Leschke (2010), 'Following the 'organising model' of British unions? Organising non-standard workers in Germany and the Netherlands', Working Paper 2010.2, ETUI, Brussels.

Vidal, S., R. Alós, P. Jódar and P. Beneyto (2014), 'Membership duration in a Spanish union: a survival analysis', Economic and Industrial Democracy, 35 (3), 507-29. 


\section{APPENDIX: LIST OF INTERVIEWS}

Marcos José Pérez

Rubén Ranz

Ana Herraez

Margarita Bravo Torres

José Domingo Roselló

Miriam Pinto Lomena

José Varela Ferrio

Carlos del Barrio Quesada

Gonzalo Pino
- Ministry of Employment, Migration and Social Security, Madrid, 17 October 2019.

- Coordinator of Turespuestasindical.es, telephone interview, 23 November 2019.

- Employment Relations Department, CEOE, Madrid, 16 October 2019.

- Social and Economic Council of Spain, Director of the International Relations and External Action, Madrid, 14 June 2019.

- Research Department UGT, Madrid, 31 October 2019.

- Employment Relations Department, CEOE, Madrid, 16 October 2019.

- Coordinator of Digitalization of Work, UGT, telephone interview, 5 December 2019.

- Head of Trade Union Action, CCOO Catalunya, Barcelona, 29 October 2019.

- Head of Trade Union Action, UGT, telephone interview, 11 December 2019. 